\title{
Building Stronger State Energy Partnerships with the U.S. Department of Energy
}

\section{Technical Progress Report Annual}

July 17, 2002 - July 16, 2003

By Kate Burke

Issued September 2003

Award Number DE-FC26-00NT40802

NASEO

1414 Prince Street

Alexandria, VA 22314 


\section{Disclaimer}

This report was prepared as an account of work sponsored by an agency of the United States Government. Neither the United States Government nor any agency thereof, nor any of their employees, makes any warranty, express or implied, or assumes any legal liability or responsibility of the accuracy, completeness, or usefulness of any information, apparatus, product, or process disclosed, or represents that its use would not infringe privately owned rights. Reference herein to any specific commercial product, process, or service by trade name, trademark, manufacturer, or otherwise does not necessarily constitute or imply its endorsement, recommendation, or favoring by the United States Government or any agency thereof. The view and opinions of authors expressed herein do not necessarily state or reflect those of the United States Government or any agency thereof. 


\begin{abstract}
This technical progress report includes an update of the progress during the third year of cooperative agreement DE-FC26-00NT40802, Building Stronger State Energy Partnerships with the U.S. Department of Energy. The report also describes the barriers in conduct of the effort, and our assessment of future progress and activities.
\end{abstract}




\section{Table of Contents}

Executive Summary

Experimental...................................................................... 7

Results and Discussion...............................................................7

Conclusion................................................................................. 14

Barriers............................................................................. 14

Assessment of Future Activities................................................ 14

Appendices.................................................................................... 15

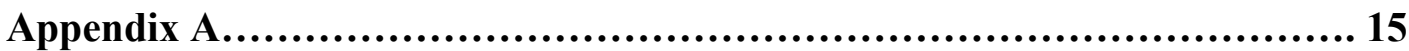

Appendix B...................................................................... 17

Appendix C....................................................................... 19

Appendix D................................................................... 21

Appendix E....................................................................... 23

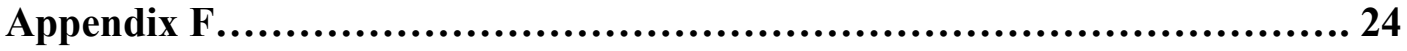

Appendix G...................................................................... 25

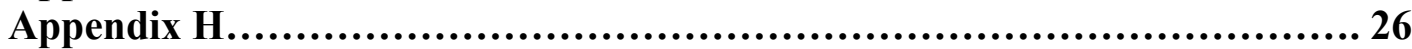




\section{EXECUTIVE SUMMARY}

When initiated by the National Association of State Energy Officials (NASEO) and the U.S. Department of Energy's (DOE), this project - Strengthening the Partnerships Between the State and Territory Energy Offices and the U.S. Department of Energy_-was geared toward addressing project development and communications barriers between the State Energy Offices and the Rebuild America program. During year two, two additional subtasks were added to Task One of the project: Subtask E Integrated Energy and Environmental Initiatives and Subtask F - Turbine Collaborative Initiative.

While successful in some states, the U.S. Department of Energy's Rebuild America officials were having difficulty assisting states in forming partnerships with communities and taking advantage of the programs technical assistance and other resources. NASEO's efforts under the project were, in large part, aimed at educating state energy offices about Rebuild America's resources and delivering timely information to help move the program forward by emphasizing the successes of key states and identifying concerns and problems in states beginning to implement Rebuild America activities. Equally important is informing DOE/Rebuild America officials regarding State Energy Office concerns and opportunities with the program. This report defines these outreach needs and challenges, the tasks designed to address these issues, and results during the third year of the project.

As contemplated in NASEO's workplan, the approach during the third year of the agreement focuses on working through NASEO's Committee structure. Most support provided under the agreement for tasks one and two during year three was intended to address partnerships in the buildings area. Specifically, NASEO was to work with its buildings committee, various state energy office members, and the Rebuild America program to improve partnership efforts, communications, and effectiveness of these combined efforts.

The approach of the project included three tasks during year three. First, NASEO and its Buildings Committee were to focus on raising awareness and coordination of Rebuild activities. Through education, one-on-one communications, and presentations at NASEO meetings and other events, staff and the committee will assist Rebuild officials in stimulating interest in the program and building greater support among State Energy Office Directors.

The most recent subtasks added to the project, though not directly related to Rebuild America, fall under this initial task, and support: a) state plans to implement integrated energy and environmental initiatives, including distributed generation technologies, and b) initiation of a state collaborative on advanced turbines and hybrid systems. The advanced turbine piece was completed during this year. During the year, a new workplan was accepted by Rebuild America's Dan Sze to supplement the work in this task. This workplan is outlined below.

Second, NASEO would work to improve the efficiency of America's schools by assisting states and DOE in promoting projects that result in more energy efficient and clean energy schools and a better learning environment. This task was fully completed during this year.

The third task involves energy security issues which NASEO addressed by way of a Summer Fuels Outlook Conference held Tuesday, April 8, 2003. The purpose of this educational event was to inform state, federal, local, and other energy officials about the most recent transportation fuels data and trends. The public benefits part of this task was not funded for Year 3, thus no activity occurred. 
The results of the first two efforts described above are a significant increase in the awareness of Rebuild America resources and assistance, as well as a better understanding of successful approaches to implementing Rebuild America activities. Additionally, the new Task One workplan provides an outline for activities moving forward, more closely following the direction of the Rebuild America program.

Also, with the addition of the new task one subtasks, NASEO worked to implement integrated energy and environmental initiatives, and assist Western states to identify collaborative research, development, demonstration, and deployment opportunities for advanced gas turbines and hybrid systems. 


\section{EXPERIMENTAL}

No experiments were conducted this year under this award.

\section{RESULTS AND DISCUSSION}

During the Year 3 reporting period, NASEO completed work for: (1) Year 1, Task 1, Subtask F; (2) Year 2, Task 2; and, (3) began work on Year 3 tasks. Midyear of Year 3, NASEO staff, in consultation with Rebuild America officials, developed a detailed workplan to refine Task 1 activities that NASEO and the Buildings Committee would like to address. Year 3, Task 2 was not funded in Year 3. Year 3, Task 3 received limited funding for a specific part of the task under energy security. An overview of the tasks and progress are presented below:

\section{Year 2, Task 1:}

Subtask F: Turbine Collaborative Initiative -

Task 1, Subtask 1a: Meet with appropriate NETL staff to identify objectives, additional issues, and other relevant information. Gather data from state energy offices, reference existing databases, and review other available information. (completed)

Subtask 1b: Plan and facilitate three group discussions with state energy officials and regional, ederal, and state government stakeholders to evaluate issues, $R \& D$ needs, and opportunities for collaborative activities that could develop between those entities and NETL. (completed) Task 2: Prepare Final Report. Identify collaborative research, development, demonstration, and deployment opportunities for advanced gas turbines and hybrid systems. (completed)

\section{Progress Detail by Task - Year 2, Task 1, Subtask F Activities (Status-Completed) Turbine Collaborative Initiative}

Task 1, Subtask 1a: Planning - Completed.

Task 1, Subtask 1b: Implementation - Completed, detailed below.

The Advanced Turbine Opportunities Workshop was held in Portland, Oregon, at the headquarters of the NWPPC on July 22, 2002. The top issue that arose out of this workshop was interconnection standards; the top needs were information and analyses of power quality; the top opportunity was state $\&$ federal utility financial incentives.

Also during this period, the Denver Advanced Turbine Opportunities Workshop was held at the U.S. DOE Denver Regional Office on August 15, 2002. From this workshop, the top issue was: the need for "best engineering" practices; the top priority was hard data analysis and case studies - education; and the top opportunity arising from the meeting was State Energy Offices' opportunity for collaboration.

The Palo Alto Advanced Turbine Opportunities Workshop was held on September 5, 2002, at EPRI. The top issue from this meeting was cost of interconnection; the top need was information and information dissemination and credible ( $3^{\text {rd }}$ party) data on emerging technology; the top priority was to relieve transmission bottlenecks.

Task 2: Final Report - The final report has been completed and can be accessed on the NASEO website: http://www.naseo.org/projects/advanced turbines.pdf. 
Year 2, Task 2: Assisting in the conduct of schools activities and other state outreach and education activities. NASEO proposes to continue the activities begun during Year 1 under Task 2 and expand upon them. During Year 2, the focus of NASEO's coordination would continue to be schools and potentially other DOE programs that may require similar outreach and education efforts. NASEO would continue to provide DOE with ongoing assistance in conducting EnergySmart Schools-related energy activities with the States. (completed)

\section{Progress Detail by Task - Year 2, Task 2}

NASEO attended the SEP/RBA National Conference from July 29 - August 1, 2002, in New Orleans, LA. At this meeting, NASEO met with NETL and NCSL to discuss the finalization of the School Decision-Maker Forums. The workshops were all completed this year and are described below.

On September 26, 2002, the Arizona Department of Commerce Energy Office completed their School Decision Maker Forum in Phoenix. The agenda included topics such as high performance schools, presented by Blanch Sheinkopf of Energy Smart Schools, utility tracking presented by three specialists from a local school district, and the workshop closed with a site tour of the Desert Vista High School (Agenda attached - Attachment A).

The North Carolina School Decision Maker Forum took place on October 8, 2002, in Chapel Hill, NC. Participants included school superintendents from around the state. Presentations included performance contracting and high performance schools guidelines. The workshop ended with a tour of the Smith Middle School, a recently completed energy efficient school building (Agenda attached Attachment B).

The Hawaii School Decision Maker Forum was held in Oahu, HI, on October 30, 2003. Attendees included School Superintendents, Board of Education members, Public Works employees, Hawaiian Electric Company employees, and Congressional Representatives. The Energy Design Guidelines for High Performance Schools and National Best Practices for High Performance Schools were presented. Attendees found the workshop to be very helpful and appreciated the afternoon's open discussion (Agenda Attached - Attachment C).

The success of these workshops has led to the State Energy Offices requesting more in the K-12 arena as well as suggesting the possibility of developing similar workshops in the college and university sector.

Year 3, Task 1 Activities: Rebuild Outreach - Raising awareness and building commitments among State energy Offices for Rebuild American and other DOE programs. This is an ongoing education task. As new staff, programs, and market opportunities evolve, there is an ongoing need for education and cooperation building among state and federal programs, resulting in levered resources and more efficient use of project funds. In addition, NASEO proposes working with DOE to expand this effort to include other programs particularly in DOE's Buildings, Power, and FEMP offices within the budget constraints of the task. (completed)

The refined workplan under Task 1 is outlined as follows and fully supports the statement of work: 
Experience from the above activities and discussions with State Energy Offices and Rebuild Staff have resulted in the identification of a number of work areas that NASEO and the NASEO Buildings Committee believe are important going forward. Each of these work areas (tasks AE) is described below:

\section{Task A. Strategic Partner Project Development and Program Input (ongoing)}

Strategic Partner activities continue to evolve and are moving toward a project orientation as witnessed by the recent NASEO-NACUBO effort to target higher education. NASEO's participation as a Strategic Partner and on behalf of the State Energy Offices is an essential activity that connects other Rebuild partner organizations with state resources and opportunities. As important is NASEO's role in offering guidance to Rebuild as Strategic Partner representing the states. The organization's input on program operation and refinement questions (along with other partner's input) is an important means of providing feedback and moving forward as a team.

The proposed task includes: 1) continuing to provide input and guidance to Rebuild via the Strategic Partner process and meetings; 2) working with Rebuild staff to identify and implement an additional strategic partner joint project opportunity similar to the higher education initiative.

\section{Task B. Higher Education Initiative (ongoing)}

Through NASEO's Buildings Committee and interested state members (e.g., New York), this task would focus on facilitating project development opportunities with NACUBO, APPA, and the states. A "kick off" presentation is scheduled for the upcoming NASEO Buildings Committee meeting. However, the real work will begin following the meeting as staff and the Buildings Committee work to encourage and assist up to three states in working with Rebuild and NACUBO to identify project partners and assist states and universities in moving ahead on energy efficiency implementation efforts.

\section{Task C. Rebuild Business Partner Outreach (completed)}

NASEO recognizes Rebuild's Business Partners as an important resource that should be utilized to a greater extent by the states and other partners. In an effort to connect these resources, NASEO will host six "issues" lunch meetings at it February 2003 Energy Outlook Conference. Each roundtable lunch would include a Rebuild Business partner speaking on a jointly defined NASEO-Rebuild topic (e.g., financing, energy management systems). This event is an excellent means for Rebuild to put business partners expertise directly in front of the State Energy Directors and potentially create greater synergy by encouraging similar activities at the state and local levels.

\section{Task D. Connecting Rebuild with State Needs and Opportunities (ongoing)}

This ongoing NASEO task would aid the states and Rebuild in the delivery of technical assistance by identifying state needs and connecting those states with Rebuild resources (e.g., contract staff, labs, web site). It would also continue to seek potential opportunities for both Rebuild and the states to act upon (e.g., new partnerships, projects). NASEO would continue to identify potential program implementation problems so that they might be resolved before derailing larger efforts.

In addition, NASEO would work with Rebuild to identify opportunities for cross deployment of other DOE program areas such as geothermal heat pumps, solar, and other distributed energy resources. This would be accomplished through targeted data collection on such state activities as defining the size and scope of public buildings programs aimed at load reduction and demand response. Data would be used to identify needs and opportunities and to enhance demonstration and deployment of technologies across sectors. 


\begin{abstract}
Task E. Enhanced Regional Coordination (ongoing)
Rebuild America's regional capabilities are quite strong, and regional offices are doing an excellent job of working with the states. NASEO believes, however, that increased coordination in the context of the reorganization of EERE and Rebuild deployment efforts is needed. Under this task, NASEO would increase coordination with the regional offices as a part of our broader commitment and communications regimen recently established with Richard Moorer and John Sullivan. This would aid in moving forward on Rebuild's efforts to be more effectively implemented across technologies. NASEO would also work to connect Rebuild America and Energy Star deployment efforts in the states.
\end{abstract}

\title{
Progress Detail by Task - Year 3, Task 1
}

The following activities comprise NASEO's Year 3, Task 1, Rebuild America-related work under the five-year NETL agreement. The activities are described based upon the requirements in the statement of work.

Task 1, Subtasks A - D, (Status - Ongoing): Rebuild Outreach - Continue the ongoing education efforts by developing and delivering Rebuild America (RA) program concepts to states. Raise awareness, build commitments, and coordinate efforts among State Energy Offices for Rebuild America and other DOE programs. Expand this effort to include other programs in DOE's Buildings, Power, and FEMP offices.

During the first half of the period, NASEO conducted and completed work under this ongoing task through one-on-one communications with State Energy Directors, distribution of Rebuild America materials and information, education of members, and inclusion of DOE's other programs. During the last half of the year, the refined Task One workplan was followed.

On September 4, 2002, NASEO attended the Strategic Partners Meeting. NASEO participated in discussion regarding college and university sector activity. NASEO reiterated the initiation of an effort which will include working with colleges/universities through RBA Strategic Partners, NACUBO and APPA, to promote energy efficiency in university.

NASEO held several meetings with NACUBO, APPA, and Rebuild to discuss opportunities in buildings energy efficiency within the college and university sector. An informal agreement to build relationships between each organization's members to further energy efficiency in college and university facilities was developed. NASEO plans to query members in the coming months regarding state activities within the college and university buildings sector. The data gathering effort to discover State Energy Office buildings energy efficiency activities within the college and university sector went out to the State Energy Offices on November 7, 2002 (Attached - Attachment D). Responses immediately came in from the SEOs. Responses portrayed activity within the sector by a majority of the SEOs and most were aware of the available tools and resources from Rebuild America and Energy Star. From this effort, NASEO combined the data into a single results report titled, "State and Territory Energy Office Activity in the College and University Sector." This report can be viewed on the NASEO website at: http://www.naseo.org/committees/buildings/documents/University_Report.pdf).

During the NASEO 2002 Annual Meeting Dan Sze and Mark Bailey presented a session titled "Rebuild America - New Tools and Synergy". The session provided attendees with information about Rebuild America tools and resources and opportunities for State-Rebuild collaboration in the future months. 
Mr. Sze and Mr. Bailey also offered both an understanding of core services and insight about the future direction of this key federal-state-community partnership program. The session description is below:

Thursday, September 19

9:15 am - 10:00 am (Crystal I - III)

Rebuild America-New Tools and Synergy

This session will deliver news you can use about Rebuild America tools and resources, as well as a look at opportunities for State-Rebuild collaboration in the months ahead. Rebuild's Daniel Sze will offer attendees both an understanding of core services and insight about the future direction of this key federal-state-community partnership program.

Moderator / Presenter: Sharon Tahtinen, Iowa

Presenters:

\author{
Mark Bailey, Technology Transfer and Market Transformation Group Leader, \\ U.S. Department of Energy \\ Daniel Sze, National Program Manager, Rebuild America, Office of Energy \\ Efficiency and Renewable Energy, U.S. Department of Energy
}

The following work was completed under Task 1, following the refined workplan (tasks A-E).

\title{
Task A. Strategic Partner Project Development and Program Input (ongoing)
}

This quarter, NASEO sponsored a Strategic Partners meeting at the U.S. Department of Energy on March 20, 2003. At the meeting, NASEO updated partners on work with NACUBO and APPA under the college and university sector, NASEO upcoming events, and the STAC program (Agenda attached - Attachment E).

NASEO held conference calls with the selected states to update them on the progress of the APPA and NACUBO relationship. States also provided ways that strategic partners could be of assistance to them.

\section{Task B. Higher Education Initiative (ongoing)}

During the aforementioned meetings with NACUBO and APPA throughout the year, NASEO suggested nine state energy offices that are focusing or plan to focus in this sector. APPA, NACUBO and NASEO with Rebuild America will build on existing relationships among members and create relationships to explore collaboration with programs and projects in colleges and universities.

During the 2003 Energy Outlook Conference, NASEO held a Buildings Committee Meeting. During this meeting, NASEO distributed the completed State and Territory Energy Office Activity in the College and University Sector results report. The results stem from the data gathering effort NASEO took on to gain a greater knowledge of SEO activity in the college sector. The report has been posted on NASEO website. Next steps include the following:

1. Coordinate exploratory meetings between interested State Energy Offices and NACUBO/ APPA members to identify potential projects and needs. In addition, assist in identifying potential State Energy Office/University partnerships.

2. Promote working relationships between State Energy Offices and corresponding identified universities and provide technical and educational assistance that facilitates project development and implementation. This would include collaboration with the Rebuild America Technical Assistance Team. 
3. Work with Rebuild America and Energy Star to promote university sector tools and resources via the State Energy Offices.

4. Pilot test a peer-to-peer university sector meeting (regionally or statewide). This would be similar to the NASEO-led K-12 School Decision Maker Forums and would be aimed at developing and sharing project implementation strategies.

5. Develop web based training materials aimed at university officials that address financing, benchmarking tools, incentives, performance contracting, and commissioning.

6. Participate in NACUBO/APPA conferences and committee meetings to better understand the energy issues facing colleges and universities, and develop appropriate strategies for successful collaboration.

\section{Task C. Rebuild Partner Business Outreach (completed)}

At the 2003 Energy Outlook Conference, NASEO hosted five Rebuild America Business Partner lunches. Each partner conducted a 1.5 hour presentation which included a question/answer period. Attendees were each provided with a disk which included all five presentations. Participating Business Partners included: Siemens, The Trane Company, Westinghouse Lighting Corporation, U.S. EPA Energy Star, and The Stella Group (Agenda Attached with speakers - Attachment F).

NASEO has updated the Buildings Committee website and added a section for the Rebuild America program. Although this link already existed, the new display of the information makes for easier access and visibility to Rebuild (Page attached - Attachment G).

\section{Task D. Connecting Rebuild with State Needs and Opportunities (ongoing)}

The State and Territory Energy Office Model Approaches to Rebuild America document has been completed. The approaches, provided by the following states: Colorado, Utah, Arkansas, California, Illinois, and New York, serve as models that other states might adopt or adapt in order to expand the reach of their Rebuild America partnerships and expedite delivery of energy savings. The document, awaiting review, will soon be posted on the NASEO website.

The aforementioned State and Territory Energy Office Activity in the College and University Sector Results Report satisfies this task as well. The results track the awareness of Rebuild America college sector tools and resources. This report has been posted to the NASEO website. From this report, NASEO has gleaned the State Energy Offices that are currently working well with universities and this has led the way for the work with APPA and NACUBO.

\section{Task E. Enhanced Regional Coordination (ongoing)}

NASEO staff collected updates on the State Energy Program Special Projects Energy and Environment grants from 2000. The states have made great progress under these grants.

NASEO staff updated Regional Office Directors on the progress of the School Decision Maker Workshops. Staff also discussed with Regional Office Directors the promotion of regional involvement in the State Technologies Advancement Collaborative (STAC) initiative. John Sullivan, Richard Moorer, and John Millhone attended NASEO June Board Meeting.

Task 1, Subtask E Activities (Status - Ongoing): Integrated Energy and Environmental Initiatives - This amended subtask supports state plans to implement integrated energy and environmental initiatives. 


\section{Progress Detail by Task - Year 3, Task 1, Subtask E}

During the reporting period, staff conducted limited follow-up activities and administrative duties attendant to the previous periods' meetings and activities (e.g., energy, environment, and transportation group meetings in September 02). Staff updated states on energy/environment and clean distributed generation activities underway in the pilot states. And NASEO conducted a meeting with the National Association of Regulatory Utility Commissioners (NARUC) to discuss cooperation on clean DG applications and to identify energy environmental needs in the states.

The "Creating Energy-Air Quality Collaboratives in the Northeast and Mid-Atlantic States" conference, co-hosted by the Ozone Transport Commission, the National Association of Regulatory Utility Commissioners, and NASEO, was held October 22-23, 2002 in Westbrook, Connecticut. The conference built upon the highly successful national and regional meetings to date on integrating the approaches of energy, environment, and public utilities. The main theme was to emphasize how to develop successful state projects and public/private partnerships that capitalize on the joint involvement and innovation of state air quality, energy, and public utility commission representatives.

Staff also attended the Mid-Atlantic Sustainability Conference, from June 4-7, 2003. The conference provided information about the most important trends in environmental business, energy, buildings, public policy, and land-use planning. The sessions allowed NASEO staff to get the newest information in high-performance buildings, public policy, and sustainable business to be shared with members.

Year 3, Task 2: Assisting in the conduct of schools activities and other state outreach and education activities. NASEO would continue to provide DOE with ongoing assistance in conducting school-related energy activities with the states and would potentially provide assistance to other DOE programs that may require similar outreach and education efforts. (Not funded during this reporting period.)

Year 3, Task 3: NASEO will continue this effort from year 2, and focus on developing collaborative projects between State Energy Office based upon the year 1 assessment and DOE and state opportunities. NASEO will focus on working with DOE program managers to provide states with training, education, and other assistance to support these cooperative efforts. IN addition, NASEO proposes assisting ODE in updating state energy emergency plans, and will facilitate regional education and cooperation on reliability and energy security issues. And NASEO would address relate public benefits and electric restructuring issue consistent with budget constraints. (This task was partially funded for the energy security section.)

\section{Progress Detail by Task - Year 3, Task 3}

Year 3, Task 3 was funded to provide a conference on the summer fuels outlook for the 2003-2004 period. The Summer Transportation Fuels Outlook Conference featured presentations from a range of private-sector and government energy experts. The purpose of this educational event was to inform state, federal, local, and other energy officials about the most recent transportation fuels data and trends. This information aided in preparing them for potential volatility in fuel supplies and prices (Agenda Attached - Attachment H). 
Specifically presented were issues concerning the world oil overview, EIA's gasoline summer outlook, petroleum refining issues, and perspectives from petroleum marketers, states, and the transportation industry. The audience includes State Energy Office directors and staff, energy industry representatives, government officials, and major media outlets.

The Summer Transportation Fuels Outlook Conference allows for the communication of vital energy supply information. As summer approaches, participants must be informed of the underlying problems with fuel supplies, outlooks, and concerns that can impact the distribution and use of fuels this season. The important information shared and issues discussed enable participants to prepare for and become more aware of the concerns they may face. In common voice, participants speak with consumers, press, and legislators regarding international tensions and effects on oil supplies, petroleum refining issues, and the perspectives of petroleum marketers, states, and transportation industry leaders on the future of summer transportation fuels. The presentations included in-depth analysis of transportation fuels supplies and trends. The link to the presentations on NASEO's website is: http://www.naseo.org/events/summer/default.htm.

\section{CONCLUSION}

\section{Barriers}

The barriers this reporting period resulted from the Year 2 work that had not been completed during the Year 2 reporting period. Ensuring that all Year 2 work was completed in this reporting period, so as not to run into the next reporting period again, was an exciting challenge. The workshops under Year 2 , Task 2, that were completed this reporting period, were all very beneficial and have resulted in new ideas for the upcoming year.

Another barrier presented itself as NASEO found there were several initiatives and projects that could potentially fit into the grant, but did not exactly match the statement of work that was created in 2000 . To remedy this, staff created a refined workplan and reviewed it with Rebuild America officials to better coincide with the direction that Rebuild America has taken and to add activities that the States and Buildings Committee suggested and were hoping to pursue.

\section{Assessment of Future Activities}

Several projects and efforts were developed during year two which focused on and strengthened the previous year's proposed shift towards promoting regional coordination, identification of new buildings sector partners (e.g. colleges, universities), and assisting states in increasing the success of their Rebuild America programs. During year 3, these strongly supported projects and efforts came to fruition and will continue as the year goes on. The new workplan allowed NASEO to add several activities that will support Rebuild America's work as well as the State's buildings programs. NASEO staff plan to create a Public Buildings Manual, work with the Buildings Committee to develop a set of State O\&M Guidelines by which states can model their guidelines, develop an effort aimed at the reduction of natural gas use in buildings, and continue the collaboration efforts of NACUBO, APPA, and State Energy Offices within the college and university sector. 


\section{Attachment A \\ School Energy Savings Workshop}

Hosted by Arizona Department of Commerce Energy Office Sponsored by National Association of State Energy Officials

\section{Agenda}

September 26, 2002

8:15 a.m. - 9:00 a.m.

Registration and Continental Breakfast

9:00 a.m. - 9:15 a.m.

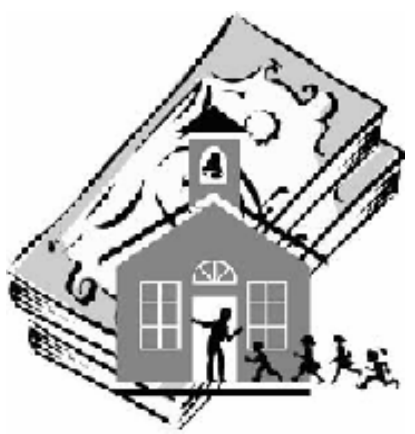

Welcome and Keynote

Craig Marks, Director, Arizona Department of Commerce Energy Office

Sandra Schneider, Governor's Policy Advisor for Energy and Homeland Security

9:15 a.m. $-9: 45$ a.m.

Why Save Energy?

Overview of House Bill 2521 and trends in western energy markets.

Presenter: Craig A. Marks, Director, Arizona Energy Office

\section{9:45 a.m. - 10:15 a.m.}

Utility Tracking

Utility data can provide information that is invaluable in the decision making process. Mesa Unified School District will summarize their experience with utility tracking and its benefits.

Presenters: Elaine B. Johnston, Expeditor/Liaison - Operations, Mesa Unified School District

Callin Jackson, Utility Specialist, Mesa Unified School District

Rick Freeman, Project Liaison, Mesa Unified School District

10:15 a.m. $-10: 30$ a.m.

Break

10:30 a.m. $-11: 00$ a.m.

Building and Operations Opportunities

Review of resources available to audit school buildings, review operation and maintenance of schools, and evaluate potential opportunities to improve the energy efficiency of a school.

Presenter: Gary Kuykendall, Energy Engineer, Arizona Energy Office

11:00 a.m. $-11: 45$ a.m.

\section{High Performance Schools}

This section presents a guide for designing schools to reduce energy consumption and costs while ensuring a productive learning environment.

Presenter: Blanche Sheinkopf, National Coordinator, EnergySmart Schools

12:00 p.m. $-1: 00$ p.m.

Luncheon

Speaker: William A. Mundell, Chairman, Arizona Corporation Commission

1:00 p.m. $-3: 00$ p.m.

Site Tour to Desert Vista High School

Learn about the district's energy-efficient policy, along with the energy saving equipment and devices used to make 
this a high-performance school. A tour bus will be provided.

1:15 p.m. - Transportation provided to school

1:30 p.m. - Arrive and tour school

2:45 p.m. - Depart

3:00 p.m. - Arrive back at hotel 
Attachment B

\section{North Carolina EnergySmart Schools Conference \\ Paul G. Rizzo Conference Center - Chapel Hill}

October 8, 2002

8:30 a.m.

9:00 a.m.

9:15 a.m.

9:45 a.m.

10:15 a.m.

10:30 a.m.

11:00 a.m.

11:45 a.m.

12:00 p.m.

1:30 p.m.

2:45 p.m.

\section{Registration and Continental Breakfast}

\author{
Welcome and Introductions \\ Larry Shirley \\ NC Department of Administration, State Energy Office \\ Ben Matthews \\ NC Department of Public Instruction
}

Are K-12 Schools in the Energy Equation? How do schools make energy decisions?

Blanche Sheinkopf, U.S. Department of Energy, Rebuild America/EnergySmart Schools

Rebuild America - Resources for Schools and Communities Vicki Heidinger, Rebuild America

Challenges and Choices Jeri Preddy, Energy Manager, Wake County Public Schools What problems do North Carolina school districts and schools face as related to retrofitting, construction, energy consumption, cost, and decision-making?

Roundtable Discussion

Sharing successes and best practices. Networking to find solutions.

\section{Creating EnergySmart Schools}

Mary McCarron, EnergySmart Schools, Ohio Energy Project

From Performance Contracting to Installation of Renewable Energy - what are the hallmarks of an EnergySmart School? How can we involve the school's "customers" in making the school EnergySmart and in reducing energy use?

Building Better Schools

Bill Mullin, Chapel Hill Carrboro Public Schools

Ken Redfoot, Corley Redfoot Zack Architects

Architectural design makes a major impact on energy use in schools.

Building High Performance Schools solutions and best practices.

High Performance Building Guidelines - Resources and Practices।

Judy Kincaid, Triangle J Council of Governments

Lunch and Discussion

Tour Smith Middle School

Bill Mullin, Facilities Director, Chapel Hill Carrboro City Schools

Evaluate and Adjourn 


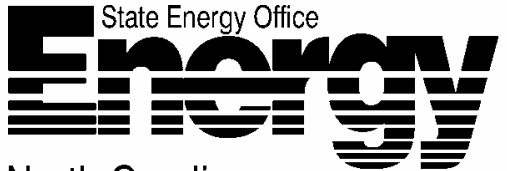

North Carolina

Department of Administration

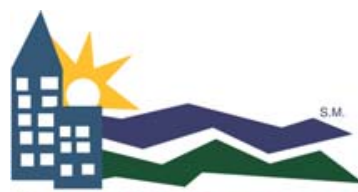

Rebuild America

U.S. Dept. of Energy

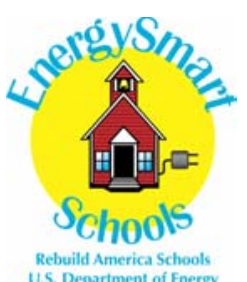

National Association of State Energy Officials (NASEO) National Energy Education Development (NEED) Project 
Attachment C

\section{AGENDA \\ Hawaii School Decision Maker Forum}

TECHNIQUES AND TOOLS TO ENHANCE LEARNING ENVIRONMENTS

October 30, 2002

Oahu Country Club

7:30 a.m. Registration and Buffet Breakfast

8:00 a.m. Executive Session

Carilyn O. Shon (Moderator), Energy, Resources, and Technology Division, DBEDT

Patricia Hamamoto, Superintendent of Education

Jackie Erickson, Vice-President, Hawaiian Electric Co., Inc.

Patricia Plympton, National Renewable Energy Laboratory

Charles Eley, President, Eley Associates

Dr. Steve Meder, University of Hawaii at Manoa School of Architecture

Maurice H. Kaya, Energy, Resources, and Technology Division, DBEDT

9:00 a.m. Break

9:15 a.m. Energy Design Guidelines for High Performance Schools—Patricia Plympton

9:45 a.m. National Best Practices for High Performance Schools-Charles Eley

10:15 a.m. Break

10:30 a.m. Guidelines for Cooling Portable Classrooms in Hawaii--Status Report-Steve Meder

11.15 a.m. Case Study on Results of Enhanced Environments - Charles Eley

11:45 a.m. Energy Smart Schools Opportunities_-Patricia Plympton, Sam Nichols

Noon-Lunch

1:00 p.m. WORKING GROUP SESSION_Leaders Charles Eley and Patricia Plympton

Objective: Apply Best Practices Guidelines and Develop a Framework for Hawaii Schools

1. Feedback on Kapolei High School

2. Pre-engineered Solutions for Daylighting, Lighting, and Insulation; HVAC

a. New Construction

b. "Portables"

3. Retrofits, Repair and Maintenance

4. Effective Educational Specifications 


\section{Co-Sponsors}

Department of Education, Hawaiian Electric Co., Inc., National Association of State Energy Officials, National Renewable Energy Laboratory, State of Hawaii DBEDT-ERTD, U.S. Department of Energy Rebuild America and Energy Smart Schools Programs 


\section{Attachment D \\ To: \\ From: \\ CC: \\ Date: \\ State and Territory Energy Offices \\ Brian Henderson (NY) \\ Janet Streff (MN), David Terry, Kate Burke \\ January 23, 2003 \\ Subject:Buildings Committee Identification of College and University Energy Efficiency Improvements}

At NASEO's recent Buildings Committee meeting, members directed staff to contact State and Territory Energy Offices to determine their activities and interest in promoting energy efficiency within the college and university sector. Following are seven brief questions that will enable the Buildings Committee and NASEO staff to identify resources and opportunities that may benefit states interested in this sector. All committee-related information can be found on the NASEO website. When complete, please forward to Kate Burke via fax: 703.299.6208; or email: kb@naseo.org.

1. Is your office involved with promoting energy efficiency or clean energy applications in the college/university sector (e.g. performance contracting)? Please circle: YES NO

2. If you responded 'Yes' to Question 1, please describe in a few sentences, and/or an attachment, your activities in this sector.

- In what sector of higher education are you working? (e.g. Public Two or Four Year; Community College; Private Institution?)

- Which campus leaders are involved (e.g. Vice President of Facilities, Vice President of Finance, etc.)?

3. What problems do you hear from the colleges and universities that keep them from participating or reduce their participation in performance contracting or related programs?

4. If your office is not involved with the college and university sector, are you interested in exploring opportunities in this sector? Please circle: YES NO

$* * * * * * * * * * * * * *$ Please continue to next page $* * * * * * * * * * * * * *$

5. If you are currently working in this sector (or are interested in doing so), what resources would be of most assistance?

Financing information or training

Benchmarking software and tools

Identification of potential partner universities

Other, please specify:

6. Are there particular activities you might recommend where states could work together with colleges and universities under a broad joint state initiative (e.g. performance contracting, new green buildings, campus energy awareness)? 
7. Are you aware of the university-related resources and/or tools (e.g. case studies, benchmarking, financing information) available from Rebuild America or ENERgY STAR? Please Circle: YES NO

Please provide your contact information:

Name

Affiliation

Phone

Fax Email

Please forward to Kate Burke via fax at 703.299.6208, or email at kb@naseo.org.

THANK YOU FOR YOUR PARTICIPATION! 
Attachment E

\author{
AGENDA \\ Rebuild America Strategic Partner Meeting \\ Location: U.S. Department Of Energy Headquarters \\ 1000 Independence Avenue, S.W. \\ Washington, D.C. \\ Conference Room 6E-069 \\ Host: National Association of State Energy Officials (NASEO) \\ Thursday, March 20, 2003 \\ Please arrive by $8 \mathrm{AM}$ in order to proceed through security.
}

(See directions on second page)

\begin{tabular}{|c|c|c|}
\hline Time & Discussion Items & $\underline{\text { Leader }}$ \\
\hline 8:30 AM & Continental Breakfast & \\
\hline 9:00 AM & Introduction \& Host Welcome & $\begin{array}{l}\text { Dan Sze \& Pat LeDonne, DOE } \\
\text { David Terry, NASEO }\end{array}$ \\
\hline 9:15 AM & $\begin{array}{l}\text { DOE's Office of Weatherization and } \\
\text { Intergovernmental Programs }\end{array}$ & John Milhone, DOE \\
\hline 9:45 AM & Break & \\
\hline 10:00 AM & $\begin{array}{l}\text { Rebuild America Report } \\
\text { RBA Annual Conference } \\
\text { RBA 2003/2004 Sector Focus: } \\
\text { - Public \& Multifamily Housing } \\
\text { - Colleges \& Universities }\end{array}$ & $\begin{array}{l}\text { Dan Sze/Mark Bailey, DOE } \\
\text { Ellen Lepper, RBA M\&C } \\
\text { Michael Nail, NAHRO } \\
\text { Lander Medlin, APPA } \\
\text { Mark Olson, NACUBO } \\
\text { David Terry, NASEO }\end{array}$ \\
\hline 11:10 PM & $\begin{array}{l}\text { Sector Spotlight: Commercial } \\
\text { - ENERGY STAR }{ }^{\circledR} \text { for Small Business } \\
\text { - APPA }\end{array}$ & $\begin{array}{l}\text { Jerry Lawson, EPA } \\
\text { Michael Hyland, APPA }\end{array}$ \\
\hline $12: 10 \mathrm{PM}$ & Lunch & \\
\hline 1:30 PM & RBA Solution Center & Dennis Clough, RBA \\
\hline 2:15 PM & Break & \\
\hline 2:30 PM & $\begin{array}{l}\text { Sector Roundtable } \\
\text { - } \mathrm{K}-12 \text { Schools } \\
\text { - } \quad \text { State \& Local Government } \\
\text { - } \quad \text { Others }\end{array}$ & Group Discussion \\
\hline 3:20 PM & Summary and Ongoing Activities & Group Discussion \\
\hline 3:30 PM & Adjourn & \\
\hline
\end{tabular}




\section{NASEO 2003 Energy Outlook Conference Agenda}

\section{February 9 - 12, 2003}

The Westin Grand, 2350 M Street NW, Washington, DC 20037

Telephone: 202.429.0100 or 1.800.228.3000

\section{Monday, February 10}

12:00 pm - 1:30 pm

\section{Energy Outlook Issues Luncheons}

- Renewable Energy's Emerging Role in Energy Security and Reliability (Suite 510)

Moderator: Terri Adams, Alabama

Presenter: $\quad$ Scott Sklar, President, The Stella Group

- New Commercially Available Lighting Technology (Chevy Chase Room)

Moderator: $\quad$ Pat Stanton, Massachusetts

Presenters: $\quad$ David Shapiro, Director, Marketing and Sales, Westinghouse Energy Group, Westinghouse

Lighting Corporation

Patricia Rizzo, Design Project Manager, Lighting Research Center

- Maximizing HVAC Mechanical Systems - Comfort System Choices (Thomas Boardroom)

Moderator: Jim Ploger, Kansas

Presenter: $\quad$ Mike Weise, Manager, Government Marketing, The Trane Company

- New DG Systems and Technologies to Aggregate and Dispatch Electricity (Dupont Room)

Moderator: $\quad$ Sara Ward, Ohio

Presenter: $\quad$ Richard Costello, Siemens

- Energy Efficiency as a Revenue Source in a Down Economy (Scott Room)

Moderator: Bill Nesmith, Oregon

Presenters: $\quad$ Neil Zobler, President, Catalyst Financial Group

Doug Gatlin, Program Manager, U.S. Environmental Protection Agency, ENERGY STAR 


\section{Attachment G - Buildings Committee}

\section{Chair: Brian Henderson, NY; Vice Chair: Janet Streff, MN}

The Buildings Committee is responsible for issues concerning public, commercial, residential, low-income, and multifamily buildings. The committee develops positions for the board's consideration and informs and educates NASEO members and the public about emerging buildings issues. Specifically, the committee monitors and researches such topics as: building codes; financing, energy improvements in schools and public facilities, and new building technologies and design practices.

Additionally, NASEO's Buildings Committee is involved with major national programs such as Rebuild America, Energy Smart Schools, and ENERGY STAR. NASEO project highlights and other information pertaining to these programs can be found here:

Rebuild America

Energy Smart Schools

NASEO ENERGY STAR Task Force

\section{Additional Information}

- Committee Information

View committee meeting minutes, correspondence, and communications for committee and NASEO members.

\section{State and Territory Buildings Programs}

Learn more about each state and territory's buildings programs dealing with public, commercial, residential, low-income and multi-family buildings.

- Status of State Energy Codes

The Building Codes Assistance Project publishes the Energy Code Bi-Monthly Report and Multi-State Commercial Code Working Group Update.

- Supporting Documents

Find information concerning buildings issues, like performance contracting and high performance green buildings, and learn more about NASEO buildingsrelated projects.

\section{$\underline{\text { Resources }}$}


Attachment $\mathrm{H}$

\section{Summer Transportation Fuels Outlook Conference Agenda}

Tuesday, April 8, 2003

Loews L'Enfant Plaza Hotel, 480 L'Enfant Plaza, Washington, DC 20024

Telephone: 202.484.1000; Facsimile: 202.646.4456

- 8:00 am - Registration and Continental Breakfast

- $\quad$ 8:30 am - Welcome and Opening Remarks

John F. Nunley, III, Chairman, National Association of State Energy Officials

Denise Swink, Acting Director, Office of Energy Assurance, U.S. Department of Energy

- 8:40 am - World Oil Overview

Dr. Herman Franssen, President, International Energy Associates, Inc.

- 9:10 am - EIA's Gasoline Summer Outlook

Guy Caruso, Administrator, Energy Information Administration

- 9:40 am - Break

- 9:50 am - Petroleum Refining Issues

Jeff Hazle, Technical Director, National Petrochemical and Refiners Association

- 10:20 am - Petroleum Marketers' Perspective

Tim Columbus, Member, Government Relations, Collier Shannon Scott

- 10:45 am - State Perspective

Gordon Schremp, Fuels Specialist, California Energy Commission

- 11:10 am - Transportation Industry Perspective

Bob Costello, Chief Economist and Vice President, American Trucking Associations, Inc.

- 11:40 am - Open Discussion

- 12:00 pm - Adjourn 